\begin{tabular}{|l|c|c|c|c|}
\hline $\begin{array}{l}\text { Cuadernos de Investigación Geográfica } \\
\text { Geographical Research Letters }\end{array}$ & 2020 & N $^{\circ} 46(1)$ & pp. 103-126 & eISSN 1697-9540 \\
\hline
\end{tabular}

DOI: http://doi.org/10.18172/cig.3796

(C) Universidad de La Rioja

\title{
LANDSCAPE-BASED FIRE SCENARIOS AND FIRE TYPES IN THE AYLLÓN MASSIF (CENTRAL MOUNTAIN RANGE, SPAIN), 19TH AND 20TH CENTURIES ${ }^{1}$
}

\author{
C.R. SEQUEIRA ${ }^{1 *}$, C. MONTIEL-MOLINA ${ }^{1}$, F.C. REGO ${ }^{2}$ \\ ${ }^{1}$ Department of Geography, Faculty of Geography and History, \\ Complutense University of Madrid, Spain \\ ${ }^{2}$ Centro de Ecologia Aplicada Prof. Baeta Neves, School of Agriculture, \\ University of Lisbon, Portugal.
}

\begin{abstract}
Wildfires have been a major landscape disturbance factor throughout history in inland mountain areas of Spain. This paper aims to understand the interaction of fire regimes and landscape dynamics during the last two centuries within a socio-spatial context. The study area selected for this historical and spatial analysis is the Ayllón massif, in the Central Mountain Range. The theoretical background used to identify the driving forces of fire regime changes over the 19th and 20th centuries in this mountain area includes landscape-based fire scenarios and fire-type concepts. Both concepts have been addressed in recent studies from a spatial planning and fire management approach in an attempt to understand current fire landscapes and wildfire risk. However, this is the first time that these concepts have been applied to show that both spatial and temporal scales are crucial for an understanding of the current wildfire panorama, and that fire history related to landscape dynamics is fundamental in socio-spatial differences in fire regimes.
\end{abstract}

Four variables (fire history, land use, population and settlement system, and forest management) were assessed to define historical landscape-based fire scenarios, and three fire feature variables (fire extent, fire cause, and spatial distribution pattern) were considered to define historical fire-types. We found that the nonlinear evolution of fire regimes during the 19th and 20th centuries was determined by fire-type changes according to landscape dynamics. Moreover, population and forest management have been the main driving forces of fire regime tipping points

1 This paper has received the First Prize and Honorable Mention from the Young Researcher Innovation Award on Mountain Areas, granted by the Research Group on Physical Geography in High Mountains, Complutense University of Madrid (Department of Geography), Spain. 
or pyrotransitions. This study validates the hypothesis that fire regime changes are the result of the interaction of fire history and landscape dynamics.

\section{Escenarios territoriales del fuego e incendios-tipo en el macizo de Ayllón (Sistema Central, España), siglos XIX y XX}

RESUMEN. Los incendios forestales han sido históricamente uno de los principales factores de trasformación del paisaje en las regiones montañosas del interior de España. El objetivo de este artículo es explicar la interacción que se ha establecido a lo largo de los últimos dos siglos entre el régimen de incendios y las dinámicas del paisaje, en su contexto territorial. El área de estudio seleccionada para llevar a cabo este estudio ha sido el Macizo de Ayllón, en el Sistema Central. Los escenarios territoriales del fuego y los incendios-tipo son los dos conceptos básicos del marco teórico empleado para identificar las fuerzas motrices de los cambios del régimen de incendios acontecidos durante los siglos XIX y XX en esta región montañosa. Ambos conceptos han sido recientemente manejados en la investigación sobre ordenación del territorio y gestión del fuego para explicar los paisajes y el riesgo de incendios. Sin embargo, es la primera vez que se aplican para demostrar la influencia de las escalas espacial y temporal en la definición del problema de los incendios forestales y para poner de manifiesto que la dialéctica histórica fuego-paisaje es fundamental para comprender las diferencias socio-espaciales del régimen de incendios en la actualidad. La valoración histórica de los escenarios territoriales del fuego se ha apoyado en el análisis de cuatro variables (historia del fuego, uso del suelo, población y sistema de poblamiento, y gestión forestal), y para la identificación de los incendios-tipo históricos se han manejado tres de sus principales características (superficie quemada, causa del siniestro y distribución espacial de los incendios). El resultado obtenido ha mostrado una evolución discontinua del régimen de incendios a lo largo de los siglos XIX y XX, como consecuencia de los cambios acontecidos en los incendios-tipo en relación con las dinámicas del paisaje. Además, la población y la gestión forestal han sido las principales fuerzas motrices de los puntos de ruptura en el régimen de incendios, denominados pirotransiciones. En definitiva, esta investigación ha permitido validar la hipótesis de trabajo que atribuía los cambios del régimen de incendios a la interacción de la historia del fuego y las dinámicas del paisaje.

Key words: fire regime, historical wildfires, land use, Spain, pyrogeography.

Palabras clave: régimen de incendios, incendios históricos, uso del suelo, España, pirogeografía.

Received: 30 October 2018

Accepted: 24 January 2019 
*Corresponding author: Catarina Romão Sequeira, Forest Geography, Policy and Socioeconomics Research Group, Department of Geography, Complutense University of Madrid, 28040 Madrid, Spain. E-mail address: anacatte@ucm.es

\section{Introduction}

Humans and fire have evolved with each other, and in their regular interaction fire has become a risk factor for human society (Pyne, 1997; Scott, 2018). Mediterraneantype climate landscapes are highly fire-prone (Keeley et al., 2012; Pausas et al., 2008). Especially from the 1980s onwards, fire risk has become a complex and challenging topic for policy-makers, land managers and operational systems (European Commission, 2017; San-Miguel-Ayanz et al., 2017; Turco et al., 2016). New planning and prevention approaches have been introduced into the research agenda, aimed at predicting fire behavior, thus providing basic information for its control and management (Cissel et al., 1999; Coughlan et al., 2012, 2013; Duane et al., 2015; O'Connor et al., 2011; Silva et al., 2010). These new fire management approaches include concepts such as fire-type and landscape-based fire scenarios (Black et al., 2005; Castellnou et al., 2010, 2009; Costa et al., 2011; LaCroix et al., 2006; Murphy et al., 2013; Pérez et al., 1998), formulated in pyrogeography, which attempts to examine the human-fire relationship from an holistic perspective (Bowman, 2015; Keeley et al., 2011; Roos et al., 2014).

The fire-type concept refers to fire spread patterns depending on the fuel load, landscape structures and synoptic weather conditions (Acebrón, 2017; Costa et al., 2011). On the other hand, landscape-based fire scenarios refer to the contextual factors of a fire regime, i.e. the environmental, socioeconomic and policy drivers of wildfire ignition and propagation on different spatial and temporal scales. In fact, fire scenarios are multiscale land-type planning units for a fire regime with different applications at national, regional, and local scales. Previous studies have addressed landscape-based fire scenarios in Spain at a national scale (Montiel-Molina et al., 2016) and a regional scale (Costa et al., 2011). Nevertheless, the local scale has not attracted the attention of many researchers, despite proof of its importance when examining the relationship between fire regime and landscape dynamics (Beilin et al., 2015; Wilbanks et al., 1999). Moreover, the vast majority of recent studies have focused on a recent time scale context (since 1968, when fire data statistics started), regardless of the fact that fire and landscape history are relevant to the current fire risk (Smith et al., 2016) and that a longer perspective is needed to characterize fire regime changes. Even though no specific data on fire behavior is available before the statistical period (which makes it difficult to apply the fire-type method), fires recorded pre-1968 do share two common features: extent and fire cause (Montiel-Molina, 2013), applicable to the definition of the historical fire-type concept.

The concepts of both landscape-based fire scenario and of fire-type therefore provide a theoretical basis to explain the dynamic character of the fire regime, through spatial and temporal dimensions (Keeley et al., 2012). Fire regime changes can be either linear or progressive, or non-linear based on tipping points, i.e. pyrotransitions, which in Mediterranean landscapes are closely related to anthropic aspects (Tedim et 
al., 2014). In general, fire regimes are linked to the environmental, socioeconomic and political contextual systems, which differ from place to place. When there is a balance between the contextual systems, the fire regime is expected to display linear progress. However, when there is an imbalance between these influencing systems, or a change in one of them, the fire regime changes abruptly, triggering a pyrotransition (Bowman et al., 2011). In this context, the concepts of fire scenario and fire-type enable the identification of pyrotransitions and an understanding of the fire regime dynamics (Krebs et al., 2010). The reconstruction of fire regimes, at a local scale and from a historical perspective, should consider some key components such as fire history, and others related to an understanding of the driving forces of fire behavior, such as land use, population and settlement system, and forest management. Recent studies have approached Spanish fire history before statistical data was available, from century time scales and based on geohistorical sources analysis (Araque, 1999; Lloret et al., 2001; Montiel-Molina, 2013), to millennial time scales through palynological and paleoecological methods (Abel-Schaad et al., 2013; Franco-Múgica et al., 2001; Gil García, 1992; Ruiz Zapata et al., 1996; Vera et al., 1984). Other studies confirm the connection between land use changes, fire behavior and landscape structure (Viedma et al., 2006). However, because long historical land use data series are unavailable, most studies of land use changes are restricted to the second half of the $20^{\text {th }}$ century (Gallardo et al., 2016; Martínez-Vega et al., 2017; Viedma et al., 2015).

This paper connects landscape-based fire scenario (LFS) and fire-type (FT) concepts from a long-term perspective ( $19^{\text {th }}$ and $20^{\text {th }}$ centuries) at a local scale in the Ayllón massif, well-known for its particular historical dynamics related to fire (Montiel-Molina, 2013). We believe that the fire regime in Ayllón Massif is non-linear, with three pyrotransitions: (1) at the end of the $19^{\text {th }}$ century; (2) in the 1970s; and (3) in the mid-1980s, facilitated by a breakdown in the balance of contextual factors. This led us to formulate our hypothesis, which proposes that the fire regime changed according to the fire scenarios, fire history and fire types, and that tracing the history of these key values will allow us to describe the fire regimes that existed in each phase between pyrotransitions. This paper attempts to answer the question of what driving forces were responsible for fire regime pyrotransitions throughout the $19^{\text {th }}$ and $20^{\text {th }}$ centuries in the Ayllón Massif.

\section{Material and Methods}

\subsection{Study area}

This case study was carried out in the Ayllón Massif, which covers $1400 \mathrm{~km}^{2}$ in the eastern part of the Central Mountain Range natural region in the Iberian Peninsula, between the provinces of Guadalajara, Segovia and Madrid (Castel, 1873; Mata Olmo et al., 2004). Slopes are steep, and altitudes range from 700 to $2272 \mathrm{~m}$ a.s.l. The climate is predominantly sub-Mediterranean with mean annual temperature around $8{ }^{\circ} \mathrm{C}$ and mean annual precipitation from $800 \mathrm{~mm}$ to over $1500 \mathrm{~mm}$ (FAO Climate data). The vegetation is very diverse, given its significant climatic variety. The most important species are Pinus sylvestris, Quercus pyrenaica, Quercus coccifera, Fagus sylvatica, and Nardus 
stricta (high mountain pastures) (Mecha-López, 2004). Two headwaters (Jarama and Sorbe) in the Tagus River water catchment area are located in the Guadalajara area of the massif, where the predominant lithology is metamorphic (black slate and gneiss), sedimentary (clay slate), and igneous (granite) (Blazquez-Díaz, 1987). The Ayllón massif is a protected National Park (Natura 2000 Network, "Sierra Norte de Guadalajara" Natural Park, since 2011), Special Protection Area for birds, and Special Conservation Area. Most of this forest area is publicly owned and is regulated and protected as Forest for Public Use. These forest areas were common land until the end of the $19^{\text {th }}$ century.

Two case study areas were selected and delimited using micro-watershed units within the Ayllón massif: (1) Sorbe and (2) Jarama (Fig.1). Both case studies consist of four micro-watersheds and cover a total area ranging from 8000 to 10,000 ha. The Jarama case study area is in the heart of the massif and covers the municipal districts of Campillo de Ranas and El Cardoso de la Sierra. The Sorbe area covers three municipal districts on the eastern side of the massif (Cantalojas, Galve de Sorbe and La Huerce) plus two districts in the heart of the massif (Majaelrayo, and Valverde de los Arroyos). All these municipal areas were considered as the spatial reference for data collection, processing and analysis.

The study area is characterized by marked human influence through natural resource management of timber, charcoal and firewood supplies, and because of the extensive afforestation campaigns in the $19^{\text {th }}$ and $20^{\text {th }}$ centuries (Fernández-Muñoz, 2002; Lopéz-

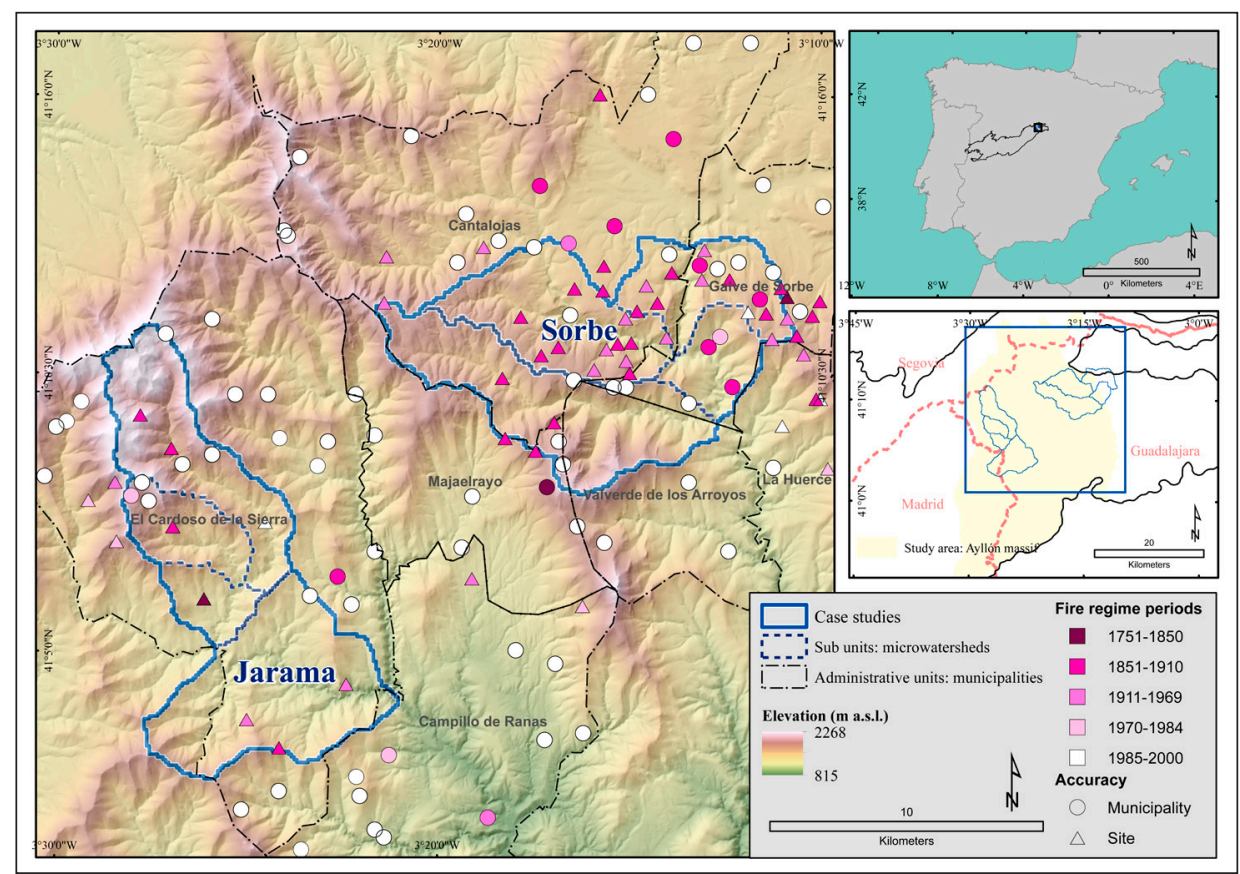

Figure 1. Study area, case studies and spatio-temporal distribution of fire occurrence. 
Gómez, 1974). Logging, grazing and hunting were historically the main activities in this forest area, with the origin of some settlements related to hunting practices (e.g. El Cardoso de la Sierra) or to livestock (with constructions known as tainas in e.g. Valverde de los Arroyos and Majaelrayo). Nowadays, the cultural landscape of the Ayllón is severely depopulated or with an aging population, where tourism has become the main economic resource for the isolated villages (Agnoletti et al., 2015).

\subsection{Data: sources and variables}

The characterization of landscape-based fire scenarios is based here on four main spatial components: (i) land use; (ii) population and settlement systems; (iii) forest management; (iv) fire history. These spatial components are analyzed in a historical and dynamic approach, according to the availability of sources and our focus on the processes (Table 1).

Table 1. Sources and data used for each variable.

\begin{tabular}{|c|c|c|c|c|c|c|}
\hline \multirow{2}{*}{ Variables } & \multirow{2}{*}{ Sources } & \multicolumn{5}{|c|}{ Data } \\
\hline & & Name & Dates & Format & Scale & Retrieved from \\
\hline \multirow{3}{*}{ Land use } & \multirow[b]{2}{*}{$\begin{array}{l}\text { Geohistorical and } \\
\text { cartographic }\end{array}$} & $\begin{array}{l}\text { Planimetric map } \\
\text { collection }\end{array}$ & $1895-1897$ & Raster & $1: 25,000$ & $\begin{array}{l}\text { Instituto } \\
\text { Geográfico } \\
\text { Nacional }\end{array}$ \\
\hline & & Ortophoto & $1956-1957$ & Raster & $1: 32,000$ & $\begin{array}{c}\text { Map Services of the } \\
\text { Gobierno Regional } \\
\text { de Castilla-La } \\
\text { Mancha }\end{array}$ \\
\hline & Geospatial & $\begin{array}{l}\text { Corine Land Cover Map } \\
2000\end{array}$ & 1999-2001 & Vector & $1: 100,000$ & $\begin{array}{l}\text { Copernicus Land } \\
\text { Monitoring Service }\end{array}$ \\
\hline \multirow{2}{*}{$\begin{array}{c}\text { Population } \\
\text { and settlement } \\
\text { systems }\end{array}$} & \multirow{2}{*}{ Statistical } & Population Census & $1864-2001$ & $\begin{array}{l}\text { Average } \\
\text { interval } 10 \\
\text { years }\end{array}$ & Municipal & $\begin{array}{l}\text { Instituto Nacional } \\
\text { de Estadística }\end{array}$ \\
\hline & & $\begin{array}{c}\text { Nomenclator Municipal } \\
\text { Registry }\end{array}$ & $1858-2000$ & $\begin{array}{l}\text { Average } \\
\text { interval } 10 \\
\text { years }\end{array}$ & Municipal & $\begin{array}{l}\text { Instituto Nacional } \\
\text { de Estadística }\end{array}$ \\
\hline \multirow{2}{*}{$\begin{array}{c}\text { Forest } \\
\text { management }\end{array}$} & Statistical & Agriculture Census & 1999 & & Municipal & $\begin{array}{l}\text { Instituto Nacional } \\
\text { de Estadística }\end{array}$ \\
\hline & $\begin{array}{l}\text { Historical Docu- } \\
\text { mentary }\end{array}$ & $\begin{array}{l}\text { Minutes of Municipal } \\
\text { council meetings, Auc- } \\
\text { tions papers and others }\end{array}$ & $1750-1990$ & Paper & Municipal & Municipal Archives \\
\hline \multirow[t]{2}{*}{ Fire history } & $\begin{array}{l}\text { Based on histor- } \\
\text { ical documentary } \\
\text { sources }\end{array}$ & $\begin{array}{l}\text { Fire history Database } \\
\text { (FHD) }\end{array}$ & Pre-1980s & Access & $\begin{array}{l}\text { Central } \\
\text { Mountain } \\
\text { System }\end{array}$ & $\begin{array}{l}\text { Forest, Geography, } \\
\text { Policy and } \\
\text { Socioeconomics } \\
\text { Research Group, } \\
\text { Complutense } \\
\text { University }\end{array}$ \\
\hline & Statistical & $\begin{array}{l}\text { Statistical Fire Database } \\
\text { (EGIF) }\end{array}$ & From 1968 & Access & Spain & $\begin{array}{c}\text { Spanish Ministry of } \\
\text { Agriculture }\end{array}$ \\
\hline
\end{tabular}

Land use changes were considered in order to understand the fuel structure from the late $19^{\text {th }}$ century to the year 2000 . The main sources and data used for this assessment were geohistorical cartographic sources (Planimetric map collection 1895-1897, in raster format, scale 1:25,000, available from the Instituto Geográfico Nacional (IGN); Ortophoto 1956-1957, in raster format, scale 1:32,000, provided by the Map Services 
of the Gobierno Regional de Castilla-La Mancha) and geospatial data sources (Corine Land Cover Map 2000, 1999-2001, in vector format, scale 1:100,000 with minimum cartographic unit 25 ha, available from Copernicus Land Monitoring Service).

Population and settlement systems were assessed to describe the human influence on the landscape. This was done through the following statistical data sources: Population Census 1864-2001, average interval 10 years, at municipal level for all 7 municipal districts covered by the case studies (available from Instituto Nacional de Estadistica (INE); and Nomenclator Municipal Registry 1858-2000, average interval 10 years, at municipal level for all 7 municipal districts (also available from INE).

The forest management component was considered to evaluate the socioeconomic value of land management and the influence of rural activities on fuel control in the case study area, using official statistical data (Agriculture Census 1999 at municipal level) and municipal historical documentary data sources.

The fire history was evaluated using the same resources as those used for analyzing historical fire types, based on three fire variables (fire extent, fire cause, and spatial distribution pattern, including the Fire History Database (FHD) and statistical fire database (Estadistica General de Incendios Forestales, EGIF). Both are Access databases sharing data to define each fire event (date, geo-location accuracy, extent, cause, etc.), but each one refers to a different period and is based on different information sources. The FHD, created by the Forest Geography, Policy and Socioeconomics Research Group in the Complutense University of Madrid, refers to the pre-1980s and is based on documentary sources (administrative documents, judicial and police sources and the press) obtained from different types of archives (historical archives, forest services and municipal archives and historical libraries). We gathered 101 historical fire records from 1768 to 1982 in the Ayllón massif study area, including 15 records for the Jarama and 46 records for the Sorbe area. All these historical fire records were geo-referenced with different levels of accuracy (from municipal boundaries to specific sites or plots) depending on the precision of the historical source. The EGIF is the official fire dataset provided by the Spanish Ministry of Agriculture since 1968 with increasing data accuracy over time (Vélez Muñoz, 2009). We used this statistical information to update the FHD until 1982, and then considered the EGIF for a second analytical period from 1983 to 2000, which includes 323 fire records (67 records for the Jarama and 56 records for the Sorbe case study).

\subsection{Methods and techniques}

Spatial and historical methods were used to integrate and analyze very diverse data series. Territorial and fire dynamics were investigated in a systemic approach, using ArcGIS for Desktop 10.3 to process the data (including photo interpretation), and qualitative analysis and basic statistical analysis techniques (Microsoft Excel 2013) for data integration. These methods were applied to process selected components to define fire scenarios (land use, population and settlement system, and forest management) and the variables considered to define fire types (fire extent, fire cause, and fire distribution pattern). 
We used two spatial analysis scales: a landscape or intermediate scale $(1: 25,000)$ for the whole Ayllón massif study area (Smith et al., 2016); and a local scale $(1: 10,000)$ to approach the Jarama and Sorbe case studies (Beilin et al., 2015). For the temporal scale, we used a long-term analysis ( $19^{\text {th }}$ and $20^{\text {th }}$ centuries) to identify the tipping-points of fire regime change and the related driving factors.

\section{Results and Discussion}

\subsection{Fire history and fire-types}

Reconstructing fire history from geo-historical documentary sources shows that fire has been an ever-present feature since at least the late $18^{\text {th }}$ century in the Ayllón massif, and particularly in the Jarama and Sorbe watersheds. 101 fire records from 1768 to 1982 were obtained for this mountain area, often related to rural activities where fire was a common land management tool (Table 2). This was why there are so many pre-1880 fire records, of small forest fires reflected in the printed press, judicial and police sources because of their social and economic impact. This human impact at a local scale explains why some wildfires are recorded in several documentary sources despite the relatively small area burned.

Table 2. Number of fire records for each period and fire database

\begin{tabular}{lcc}
\hline & FHD (1768-1982) & EGIF (1983-2000) \\
\hline Ayllón massif & 101 & 323 \\
Jarama case study & 15 & 67 \\
Sorbe case study & 46 & 56 \\
\hline
\end{tabular}

*FHD: Fire History Database; EGIF: Statistical Fire Database

The first large wildfire was recorded on August 15, 1891 in the public forests in Riaza (Segovia) with three simultaneous ignitions, burning 119 ha. Other large wildfires were recorded in 1954, 1970, 1978 and 1983. Since 1991 - when three large wildfires were recorded - this type of fire situation, the increasing number of ignitions and the variability of fire behavior have defined the present fire regime of uncertainty in the Ayllón massif.

According to the fire history of this massif, three shifts or pyrotransitions have been identified in the fire regime dynamics in the $19^{\text {th }}$ and $20^{\text {th }}$ centuries (Fig. 2). These fire regime shifts occurred especially (i) in the late $19^{\text {th }}$ century/early $20^{\text {th }}$ century, with increased fire occurrence; (ii) in the 1970s, when a few fires caused a large burnt area; (iii) in the $1980 \mathrm{~s}$, when fire occurrence increased again, leading to a new uncertainty scenario. In short, from the late $19^{\text {th }}$ century until the year 2000 , there was a shift in the Ayllón from a situation where fire was used as a management tool in everyday rural activities to one where the fire risk is unexpected and uncontrolled. 


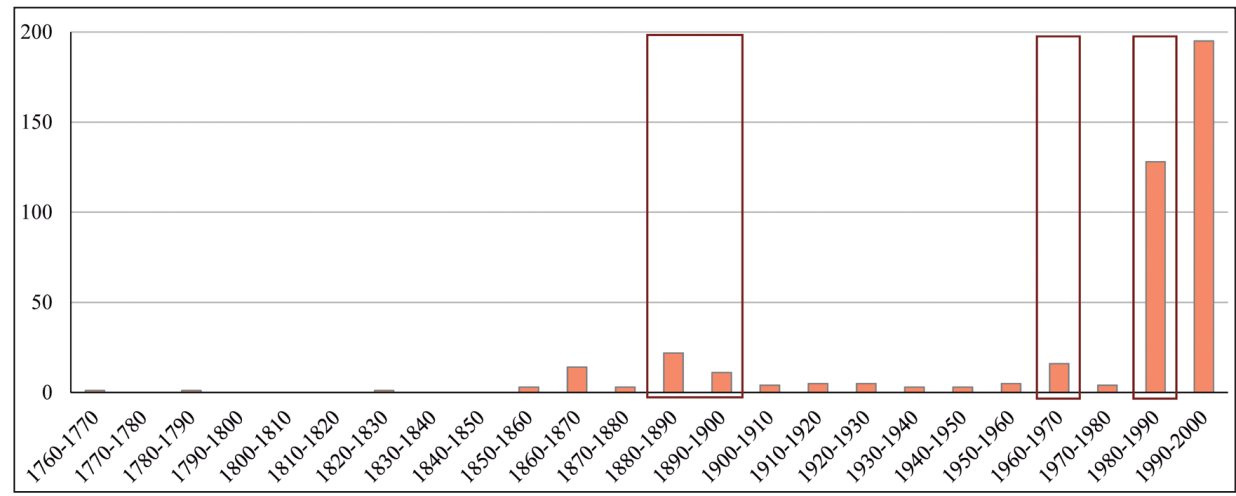

Figure 2. Number of fires recorded in the Ayllón massif and tipping-points (or pyrotransitions) of the fire regime dynamics (rectangles).

The drivers leading to the present fire regime have historical roots at the local level. In fact, significant differences were found between the two local case studies. The Jarama area was historically less affected by wildfires than the Sorbe watershed, although the opposite was true during the statistical period (see Table 2 and Fig. 3a). Nevertheless, the evolution of the burnt area has been different in both areas and is greater in Sorbe than in Jarama since 1984 (Fig. 3b).

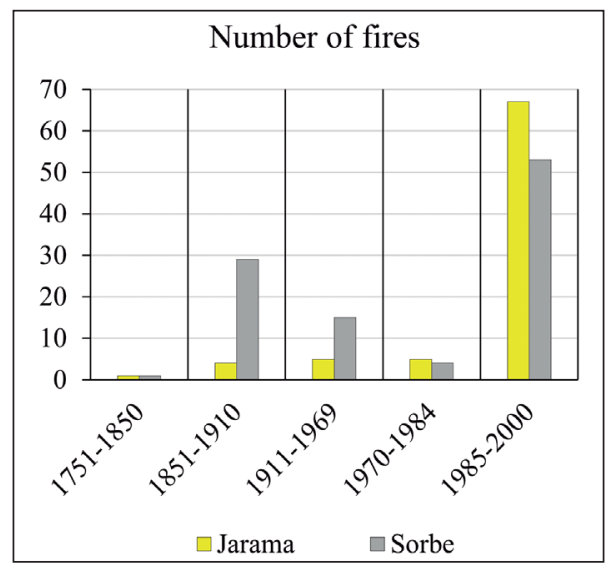

Figure 3a. Occurrence of fires in Jarama and Sorbe.

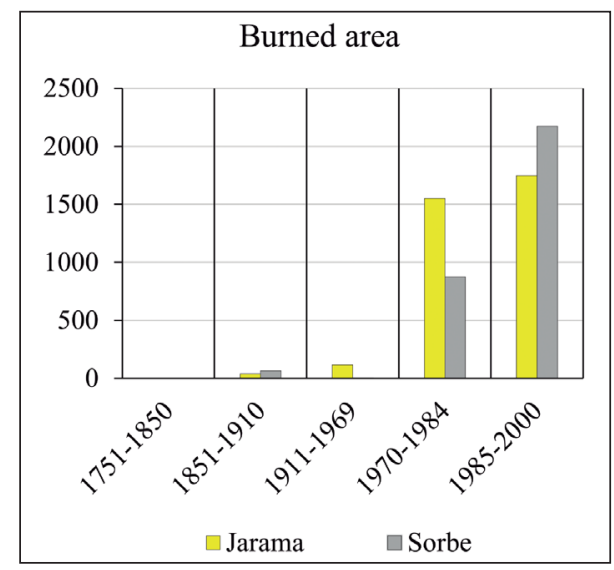

Figure $3 b$. Extent of fires in Jarama and Sorbe.

Historical fire types were analyzed during the five periods identified according to the three pyrotransitions mentioned above and the tipping-point recognized by the mid- $19^{\text {th }}$ century resulting from the socioeconomic effects of Forest Administration regulations in the context of Liberalism. Thus, fire types have been characterized in each period according to their main features, i.e. fire size, fire cause, and spatial 
distribution pattern. Fire size is classified as follows: (i) very small fire, $<1$ ha; (ii) small fire, 1-15 ha; (iii) medium size fire, 15-100 ha; (iv) large fire, 100-500 ha; (v) very large fire, $>500$ ha. These numerical thresholds were established from a thorough analysis of historical events, considering that a small historical fire usually represents an accident, i.e. loss of control in the use of fire, and is extinguished by efficient community-based suppression systems. In contrast, what are usually called large historical fires in the documentary sources are normally larger than 100 ha and demonstrate the inefficiency of local suppression systems.

On a local scale, the first very large wildfire ( $>500 \mathrm{ha}$ ) is recorded in the $1970 \mathrm{~s}$ in the Jarama watershed, and ten years later in Sorbe (Fig. 4). In both cases, the ignition trends and burnt areas, and the occurrence of very large wildfires, suggest that the last pyrotransition is marked by a large wildfire episode resulting from the destabilization of the entire socio-spatial system. This destabilization occurred later - although with more abrupt effects - in the Sorbe watershed as a result of landscape dynamics related to the fire use practices maintained until the second pyrotransition in the 1970s. However, very large wildfires remain exceptional events in the Ayllón massif due to the rural character of the landscape and the socio-economic dynamics. Currently, small and very small fires are the main sizes observed in this mountain area.

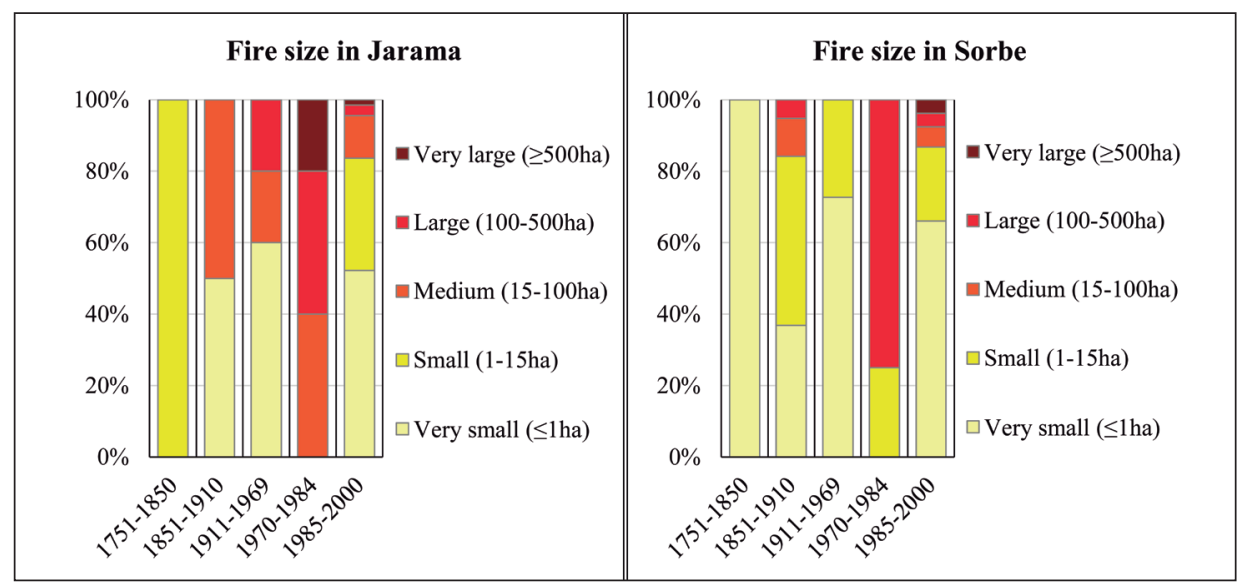

Figure 4. Fire size in Jarama and Sorbe.

For the direct causes of fire, four major ignition groups have been identified in the Ayllón massif: (i) burning for pasture renewal/agriculture/forest activities, (ii) intentional/arson, (iii) natural/lightning, and (iv) negligence/accidental/other. It was found that for this variable, the two case studies were historically fairly similar (Fig. 5). Despite the limitations of the historical documentary sources, the available data show that burning for pasture renewal/agriculture/forest activities and negligence/accidental/ other were the two main causal factors of fire in the Ayllón massif until 1984. Since then, intentional/arson fires are the most prevalent, particularly in the Jarama watershed, 
due to the breakdown of the traditional land management system and the introduction of new lifestyles which increased fires from arson in the late $20^{\text {th }}$ century. Also notable is the high proportion of fires from natural causes here at the eastern end of the Central Mountain Range (Vélez Muñoz, 2009).

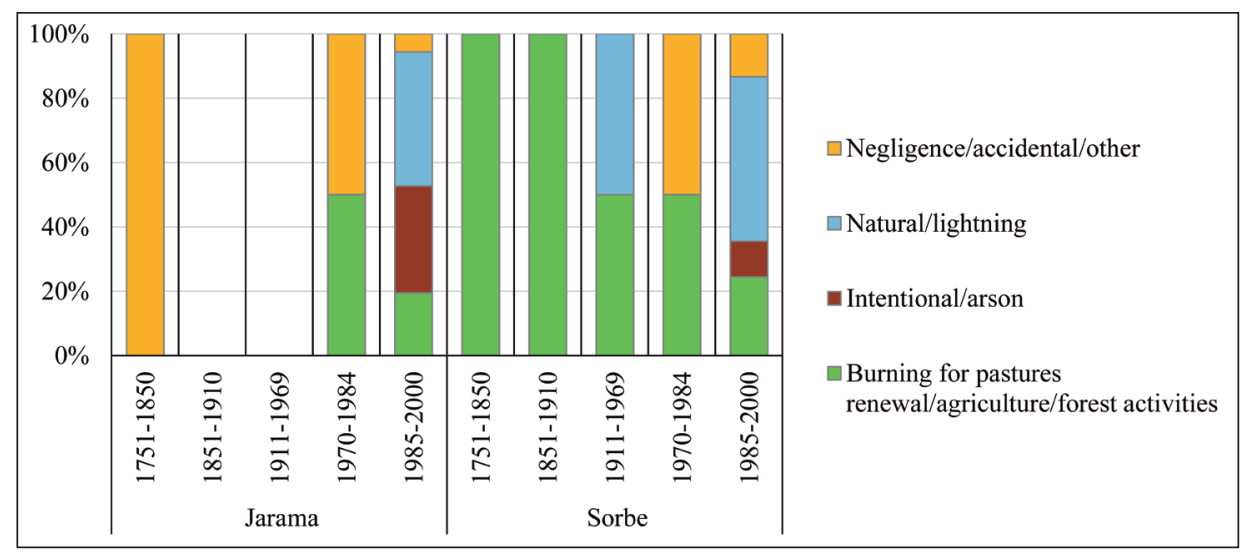

Figure 5. Fire causes in Jarama and Sorbe.

For the spatial location pattern, historical fires were geo-referenced according to the information recorded at two levels of accuracy: (a) municipality, and (b) plot/site. The municipal level includes historical fire records where documentary sources do not provide information about the precise ignition site, and pre-2000 statistical records without geographic coordinates. Plot/site refers to historical fire records with spatial information about the fire ignition and the statistical records since 2000 with geographic coordinates. Despite these constraints, the space-time analysis of the location of historical fires at local level obtains a concentrated pattern of fire records over time in Sorbe, meaning a fire resilient landscape (San-Miguel-Ayanz et al., 2017) in comparison with the relatively random pattern and fire deficit in Jarama (Fig. 1).

\subsection{Population dynamics and settlement system}

The cultural landscape of the Ayllón massif is linked to the demographic dynamics, population lifestyle and rural practices. This mountain area located in the Spanish central region of Castilla benefitted only barely from the legislative progress in civil affairs during the period of the Second Republic, which just brought about a slower rate of population decline since the first census (1877) in contrast with the general positive trend in the country as a whole (Fig. 6). The social and cultural stagnation lasted until the 1960s during the Franco dictatorship (Ussel, 1990). Then, the economic development and cultural changes in Spain linked to the industrialization process and urban growth led to the rural exodus and abandoning of agrarian activities in mountain areas in the interior (Jerez et al., 2004). This is particularly evident in Sorbe and Jarama, where the decline in population and rural activities 


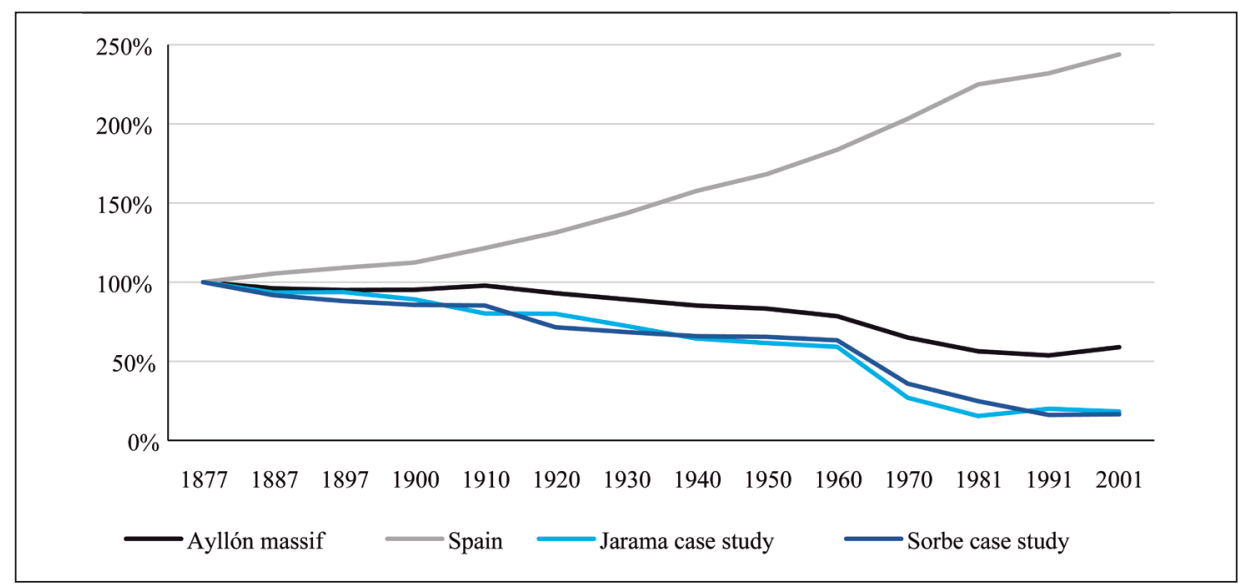

Figure 6. Relative demographic evolution of Spain, Ayllón massif, Jarama and Sorbe case studies.

continued until the recovery in the 1980s in Jarama and in the 1990s in Sorbe, due to official local development policies co-funded by the European Union (Montiel-Molina, 2003).

As a result of this long secular decline in the Ayllón massif (from 20,539 inhabitants in 1877 to 15,154 in 2001), the population density in 2001 was lower than four inhabitants per $\mathrm{km}^{2}$, which is considered by FAO as a severe under-population problem. In fact, the Ayllón massif is one of the mountain areas in central Spain included in the European high-risk fire scenarios of disadvantaged rural areas (Montiel et al., 2010).

Table 3. Population and settlement system dynamics.

\begin{tabular}{ccccc}
\hline & \multicolumn{3}{c}{ Population density of the settlement system $\left(\mathrm{Inhab} / \mathrm{km}^{2}\right)$} \\
\hline Case study & \multicolumn{3}{c}{ Jarama } & \multicolumn{3}{c}{ Sorbe } \\
Year & $\mathbf{1 9 0 0}$ & $\mathbf{2 0 0 0}$ & $\mathbf{1 9 0 0}$ & $\mathbf{2 0 0 0}$ \\
\hline Small villages & 2.37 & 0.34 & 6.84 & 1.54 \\
Scattered populated areas & 0.08 & 0.09 & 0.01 & 0.01 \\
\hline
\end{tabular}

\subsection{Land use changes}

The present forested landscape characterizing both Sorbe and Jarama is the result of similar land-use dynamics throughout the $20^{\text {th }}$ century, re-shaping the very different cultural landscape in each watershed at the end of the $19^{\text {th }}$ century. Although shrublands were the predominant land-use in both areas 1895-1897, Jarama had a significant agricultural area, mainly in the central and southern sectors, while Sorbe was entirely woodland. However, by 1999-2001 both Sorbe and Jarama had a very similar forested landscape, with approx. $58 \%$ forest, $5 \%$ pasture and the remaining area shrubland (Fig. 7). 


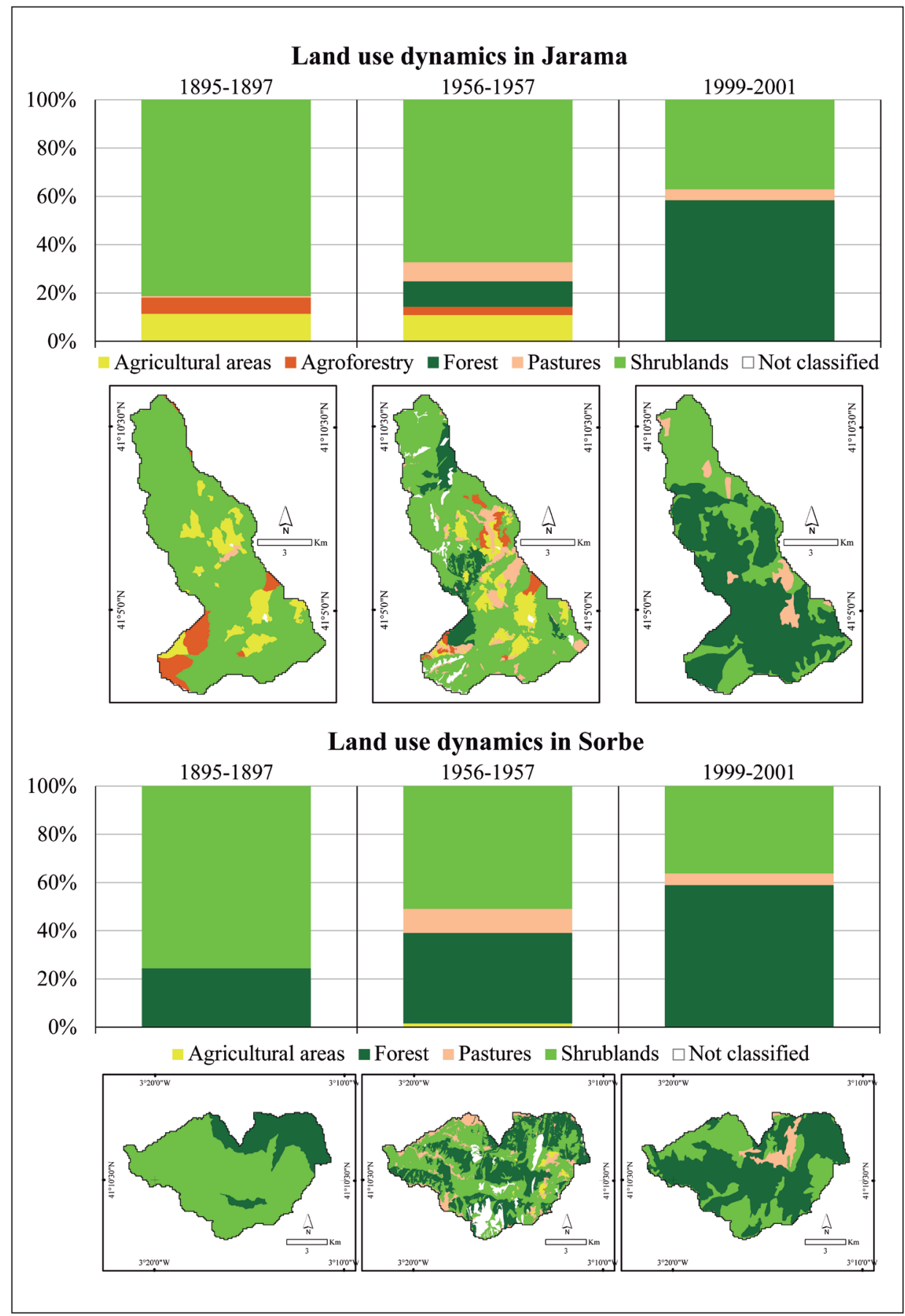

Figure 7. Land use dynamics in Sorbe through the 19th and 20th centuries (1895-1897, 19561957 and 1999-2001) in Jarama and in Sorbe case studies. 
Forest land use had increased considerably in the Ayllon Massif by the end of the $20^{\text {th }}$ century. However, the dynamics of the land use change were completely different in the first and in the second half of the century. In the first fifty years a growing trend to forest regression and general maintaining of other land uses can be observed in both Jarama and Sorbe, while the most striking trend since the 1950 s is the general forest progression. With these contrasting dynamics, the formerly diverse landscape structures have become increasingly uniform and unstable, particularly in Jarama (Fig. 8).

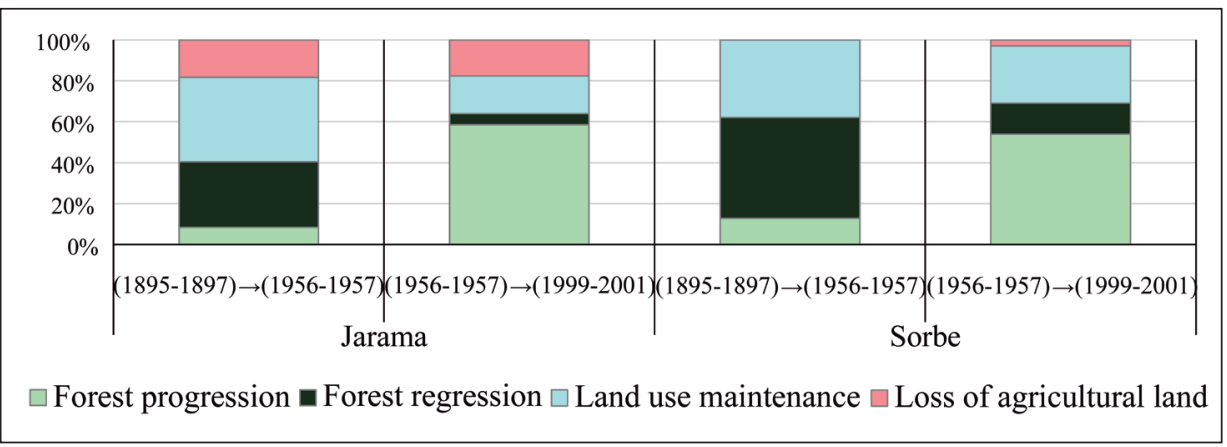

Figure 8. Land use changes in Sorbe and in Jarama in (1895-1897) - (1956-1957) and (19561957) - (1999-2001).

The main factors influencing these contrasting dynamics of land use change and the related landscape uniformity and instability are the official polices of expropriation ( $19^{\text {th }}$ century) and reforestation (20 ${ }^{\text {th }}$ century) (Fernández-Muñoz, 2002; FernándezMuñoz et al., 2000). The Common Agricultural Policy (CAP) Reform measures have also contributed to recent forest progression through afforestation programs (Vadell et al., 2016). In addition, the abandonment of rural mountain areas in inland Spain in the 1960s resulted in the loss of traditional land management practices and the generally uncontrolled progression of woodland (Stellmes et al., 2013; Tolón Becerra et al., 2007).

\subsection{Forest resources management and regulation}

Historically, forest management played a major role in the socioeconomic organization of rural areas in the Ayllón massif. The large number of local regulations and related permits, and reports on illegal activities, are a good indicator of the critical value of forest resources for the subsistence economy in both Jarama and Sorbe. Timber and firewood extraction were the main forest products in both areas, while communal grazing was also a widespread forest management practice, mainly with transhumance from Extremadura and Andalucía (Blanco, 1993; Comíns et al., 2011) (Fig. 9).

Grazing was a widespread forest management practice in the rural areas of the Central Mountain Range, and livestock density remained relatively stable in the Ayllón massif until the mid-20 $0^{\text {th }}$ century (Lopéz-Gómez, 1974). However, certain variations can 


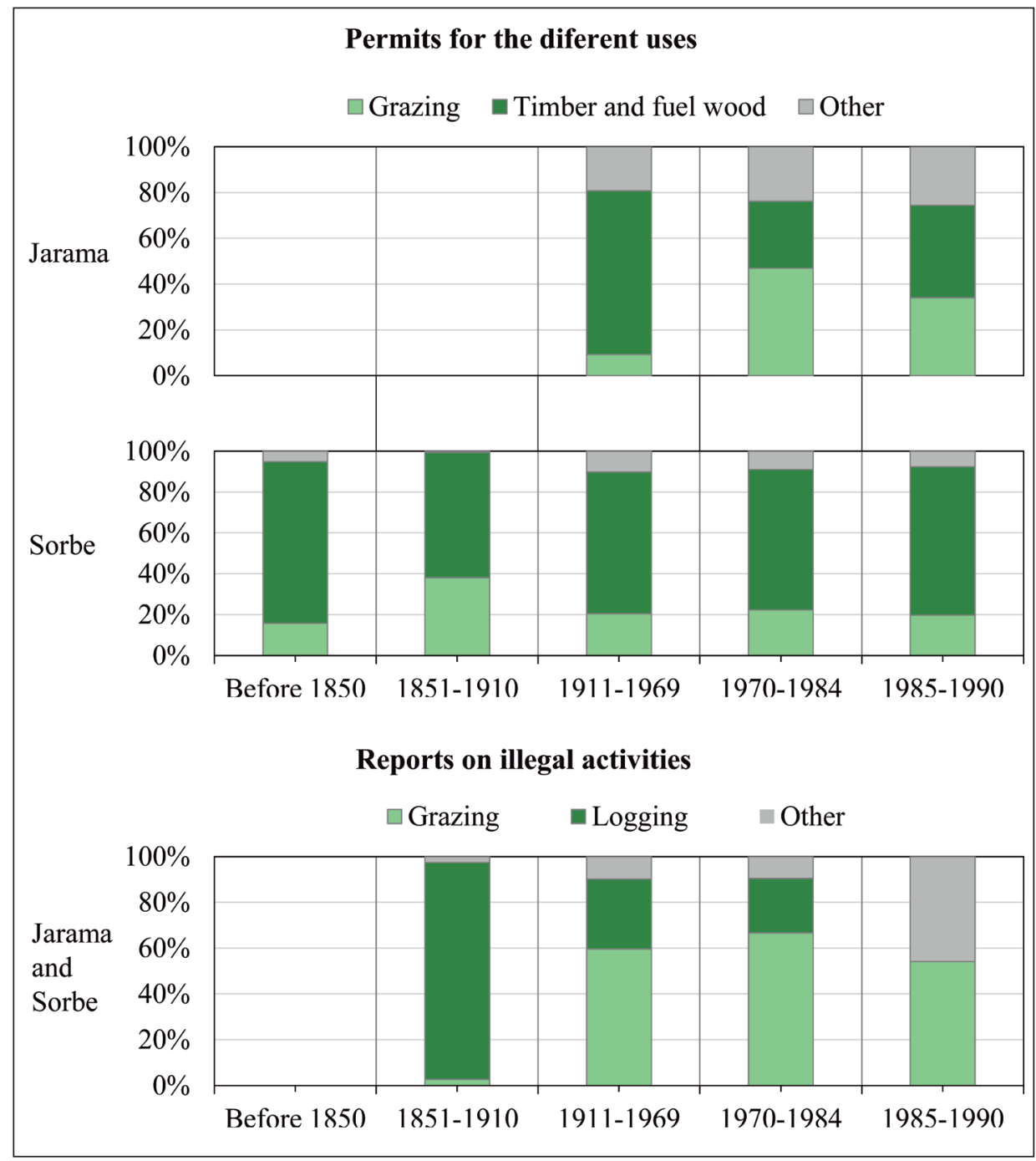

Figure 9. Social indicators of forest resources management until 1990.

be seen at the local scale. In Sorbe, livestock density increased during the period 19111970, mainly due to an open-range livestock grazing trend in the 1930s and 40s for meat production. Then, in the 1970s, the traditionally predominant sheep and goats almost disappeared, in contrast with a sustained or even increased trend to cattle rearing in Jarama (Fig. 10).

Reports on illegal forest uses mostly relate to grazing activities since 1911 and refer to conflicts between local inhabitants because of a shortage of pastureland. The subsequent period (1970-1984) highlights that conflictive situation further, largely due 


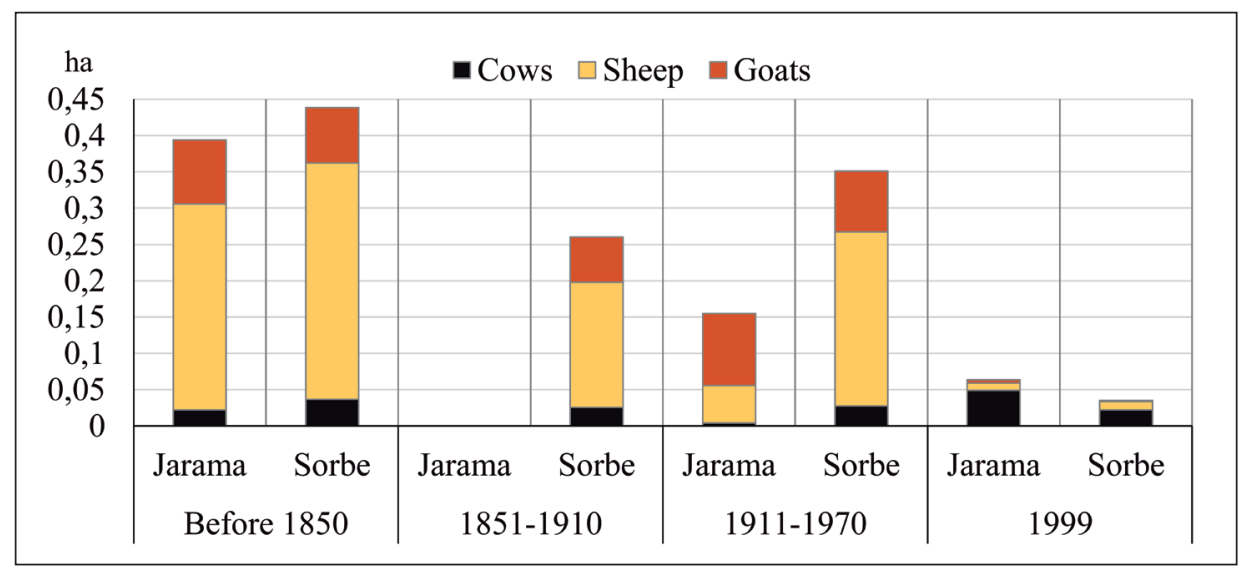

Figure 10. Average livestock density (number of livestock per hectare) in Sorbe and Jarama.

to the implementation of EU afforestation programs. We suggest that grazing activities in the Ayllón massif retained their social non-economic value, but because they were not organized on a consensual basis, they generated regulatory problems and illegal grazing activities. The last period (1985-1990) evidences some degree of chaos, since the number of reports on illegal forest uses other than logging and grazing increased sharply. On the other hand, most illegal logging conflicts seem to have been solved in the Ayllón massif in this last period analyzed (Fig. 9).

Other contextual factors of local conflicts related to forest resource management are the consequences of the expropriation process in the $19^{\text {th }}$ century. The subsequent municipal management system and legal protection of forest for public use led to many different systems of community-based management regulations in Sorbe and Jarama (Montejano, 1988), originating an increasing number of reports of illegal uses of the forest (Fig. 9). In fact, the province of Guadalajara is one of the areas which best represents the expropriation process in the latter half of the $16^{\text {th }}$ century, leading at that time to the start of the demographic decline, livestock recession, deforestation, and the socio-spatial reorganization of agricultural areas. Nevertheless, these privatization processes of forestland were not significant in the Sorbe and Jarama rural areas (GómezMendoza, 1967). On the contrary, new land management regulations introduced by the Forest Administration in the second half of the $19^{\text {th }}$ century, and hydrological and forestry policies in the $20^{\text {th }}$ century, disrupted the land ownership structure and sociospatial systems in the area.

Following the mid-20 ${ }^{\text {th }}$ century transition of rural society, the forest resource management system was not adapted to the new socioeconomic situation (Paniagua et $a l ., 2001)$. The trend to an aging population and decreasing active population continued, despite the new opportunities emerging from local development policies (Delgado Viñas, 2015; Pascual, 2006). Furthermore, this mountain area lost its importance as the main 
supplier of forest products to Madrid and further isolated itself by accentuating traditional economic rural activities and forest uses, mainly in Sorbe (Hernando et al., 2016).

\subsection{Shaping the landscape-based fire scenarios}

Both the fire regime and territorial dynamics have changed throughout the history of the Ayllón massif, which explains the presence of different fire risk situations and territorial fire scenarios. As multiscale land-type planning units, the current landscapebased fire scenarios at the national scale are the massifs and forestry ranges of the Central Mountain Range and mountain massifs and ranges, southwestern peneplains, characterized by scarcely-populated, predominantly forested areas with high/medium propagation capacity and low agricultural presence (Montiel-Molina et al., 2016). At the regional scale, the Sorbe and Jarama watersheds are both within the forestland use scenarios of first and second wildfire generations. The first wildfire generation scenarios refer to long perimeters and high propagation velocity fire behavior due to the continuity of the forest mass as a result of agricultural abandonment. The second wildfire generation scenarios imply complex, high intensity wildfires with high propagation velocity because of increased fuel load from the abandoning over time of farmland and traditional forest management (Costa et al., 2011; Montiel-Molina et al., 2018).

The Ayllón massif is a mountainous area in the interior of the Iberian Peninsula characterized by its isolation from the main road networks, reduced croplands and scarce population dependent on small-scale domestic agriculture and livestock activities, mainly open-range beef cattle rearing (Allende et al., 2014; Paniagua et al., 2001). However, fire risk is more dependent on socio-ecological conditions at the local scale, than on the socio-spatial character at the regional scale. Our data shows that the Jarama watershed comprises the most underpopulated municipality of the Ayllón massif and it is characterized historically by a lower occurrence of wildfires. On the other hand, the Sorbe area is less suitable for agriculture, with more forest resources and a higher impact of historical wildfires.

The four variables selected to define the historical landscape-based fire scenarios - fire history, land use, population and settlement system, and forest management - can be qualitatively ranked in order of importance for the shaping of current fire scenarios. The two most influential variables are land use and forest resources management and regulation. The other two variables - population and settlement, and fire history - play a secondary supporting role, enhancing the dynamics generated by the two leading variables. We argue that no single fire scenario can be defined for each local case study since there is insufficient data available on historical fire behavior, but instead the dynamics of each variable can be reconstructed to analyze their interactions (Table 4).

In short, we have identified three different spatial-temporal fire scenarios in the Ayllón massif since the late $19^{\text {th }}$ century:

The socio-ecological context in the period between the two pyrotransitions identified (from the end of the 19th century to the 1970s), characterized by overall forest regression dynamics, decreasing population and livestock density, and increasing fire occurrence. 
Table 4. Fire scenarios variables.

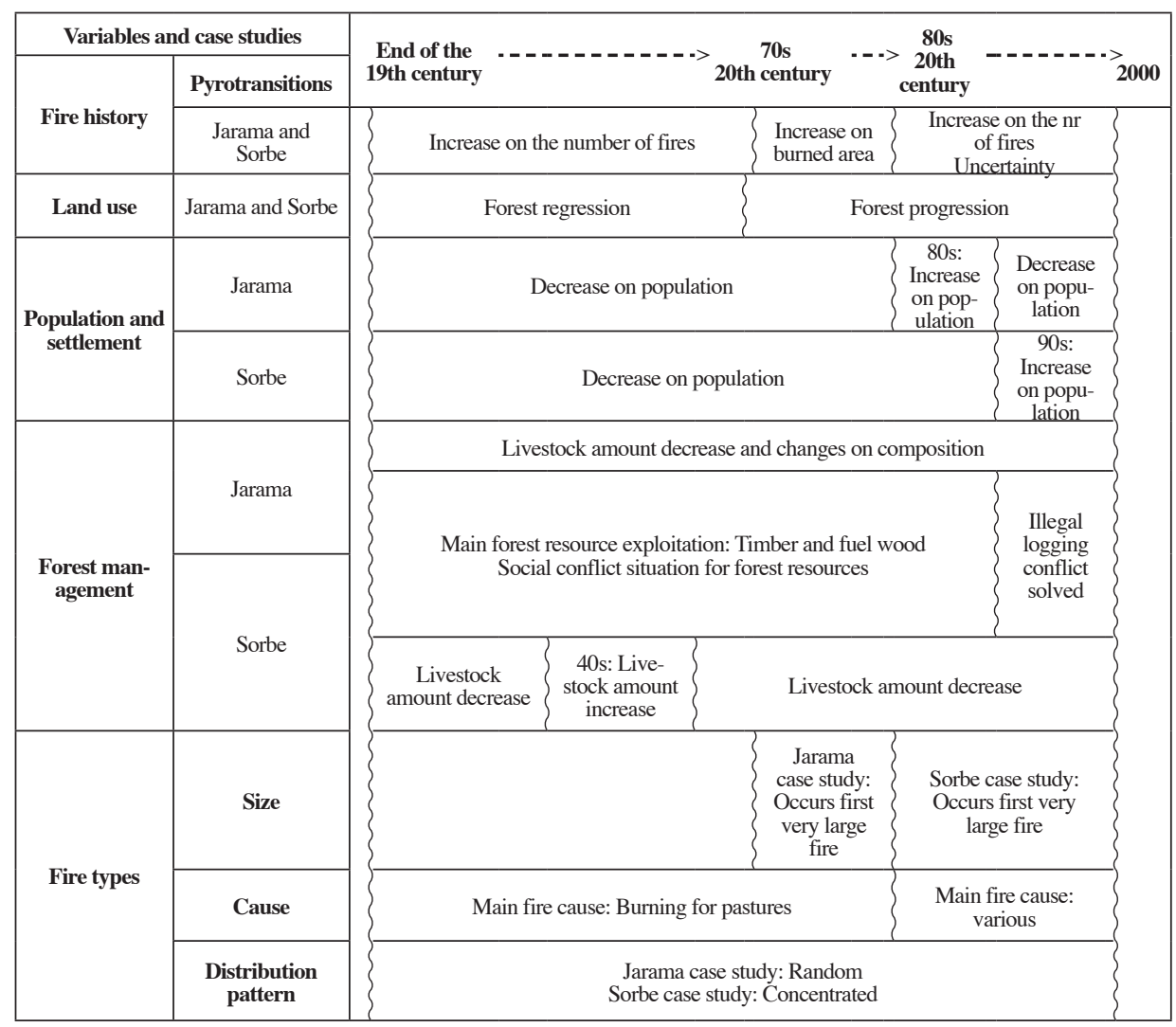

This was a still a relatively stable fire scenario, because despite the increasing number of fires and conflicts related to the grazing practices in communal areas, the main causes of wildfires were still connected with traditional rural activities in Sorbe and in Jarama.

1. The contextual factors of wildfires from the second to the third pyrotransition (1980s) linked to major land use change that led to widespread forest progression and a significant increase in the burnt area. In this fire scenario, the agricultural character of the Jarama area was lost, the equilibrium of the socioecological system was disrupted, and the first very large fire was recorded. Forest and shrublands spread while the management of forest resources was abandoned. In addition, changes in population structure seem to have altered the socio-ecological system, especially in Jarama where depopulation was even more pronounced. Moreover, the processes of agricultural industrialization, rural exodus, land abandonment, change in traditional rural practices, and energy transition from the use of biomass to fossil fuels, caused landscape homogenization, generally favoring wildfire occurrence in the last decades of the $20^{\text {th }}$ century. 
2. From the third pyrotransition onwards, the occurrence of fire events increased sharply in a context of growing uncertainty. The causes of fires changed as a result of the shifting social system, and the socio-ecological equilibrium of Sorbe was lost, ten years later than Jarama. Local conflicts related to grazing activities and lack of governance mechanisms for conflict resolution led to a scenario of very high fire risk, depending on extreme meteorological situations in the Ayllón massif (Pausas et al., 2012; San-Miguel-Ayanz et al., 2017).

\section{Conclusions}

The interactions between landscape dynamics and fire regime do not display linear progressions in time or space in the Ayllón massif. The rural fire culture, prevalent for centuries, meant that fire was commonly used as a land management tool in this rural context (i.e. frequent but controlled use of fire for the maintenance of pastureland). At historical moments of socio-ecological crisis and system instability (e.g. the establishment of the forest administration in the $19^{\text {th }}$ century or the rural abandonment in the $20^{\text {th }}$ century), the frequency of fire occurrence and the burnt area increased. In the Ayllón massif, the influence of the socio-ecological system on the fire regime was evidenced through the pyrotransitions identified in the late $19^{\text {th }}$ century, in the 1970 s, and in the mid-1980s.

Reconstruction of the fire history and analysis of key socio-spatial variables of landscape dynamics in the $19^{\text {th }}$ and $20^{\text {th }}$ centuries have enabled us to describe the spacetime context of wildfires at a local scale and to demonstrate the influence of historical landscape dynamics as the driving forces of the present fire scenarios in Sorbe and Jarama.

The main driving forces shifting fire regimes and shaping fire scenarios in the Ayllón massif during the $19^{\text {th }}$ and $20^{\text {th }}$ centuries were forest resource management and land use changes. These same drivers and processes took place in all Mediterranean countries to different degrees (Millington et al., 2007), and were significantly shaped by human societies throughout history, closely related to fire use practices, particularly for agriculture and grazing purposes (Keeley et al., 2012; Mazzoleni et al., 2004; Silva et al., 2010). This means that in all Mediterranean countries the same set of sociospatial variables considered in our study are drivers of landscape change, and the spatial differences of fire types are mainly related to contrasting timelines and to specific local conditions (Beilin et al., 2015). Thus, the strong connection between past socioecological dynamics and current landscape structures is a convincing argument in favor of the major role of history in our understanding of current scenarios and fire regimes (Smith et al., 2016).

\section{Acknowledgements}

This study is part of the $\mathrm{PhD}$ Thesis developed by $\mathrm{C}$. Sequeira under the supervision of C. Montiel and F. Rego. This PhD has been funded by the Spanish Science Ministry (BES-2014-068696) and is being conducted within the Spanish National Research 
Project FIRESCAPE (CSO2013-44144-P) in the Research Group of Forest Geography, Policy and Socioeconomics at the Complutense University of Madrid.

\section{References}

Abel-Schaad, D., López-Sáez, J.A. 2013. Vegetation changes in relation to fire history and human activities at the Peña Negra mire (Bejar Range, Iberian Central Mountain System, Spain) during the past 4,000 years. Vegetation History and Archaeobotany 22 (3), 199-214. https:// doi.org/10.1007/s00334-012-0368-9.

Acebrón, M.L.G. 2017. Tipificación de los incendios forestales en la provincia de Guadalajara (Castilla-La Mancha). Foresta - Asociación y Colegio Oficial de Ingenieros Técnicos Forestales 67, 32-39.

Agnoletti, M., Santoro, A. 2015. Cultural values and sustainable forest management: the case of Europe. Journal of Forest Research 20 (5), 438-444. https://doi.org/10.1007/s10310-0150500-7.

Allende, F., López, N. 2014. Las Sierras del norte de Guadalajara: de los comunes de villa y tierra al paisaje de las repoblaciones forestales. In: F. Molinero Hernando (Coord.). Atlas de los paisajes agrarios de España. Ministerio de Agricultura, Alimentación y Medio Ambiente, Madrid, pp. 879-884.

Araque, E. (Coord.). 1999. Incendios históricos. Una aproximación multi-disciplinar. Universidad Internacional de Andalucía, Baeza. 422 pp.

Beilin, R., Reid, K. 2015. It's not a 'thing' but a 'place': reconceptualising 'assets' in the context of fire risk landscapes. International Journal of Wildland Fire 24 (1), 130-137. https://doi. org/10.1071/WF14935.

Black, A.E., Opperman, T. 2005. Fire Effects Planning Framework: user's Guide. General Technical Report GTR-RMRS- 163WWW. USDA, Forest Service, Rocky Mountain Research Station. 63 pp.

Blanco, D.R. 1993. Ganados y señores en la Extremadura medieval. In: S.R. Becerra (Ed.). Simposio Trashumancia y Cultura Pastoril en Extremadura. Asamblea de Extremadura, Mérida, 376 pp.

Blazquez-Díaz, A. 1987. Estudio geomorfológico del valle de Majaelrayo (Sierra de Ayllón, Guadalajara). Eria. Revista de Geografia 12, 43-60.

Bowman, D.M.J.S. 2015. What is the relevance of pyrogeography to the anthropocene? Anthropocene Review, 2 (1), 73-76. https://doi.org/10.1177/2053019614547742.

Bowman, D.M.J.S., Balch, J., Artaxo, P., Bond, W.J., Cochrane, M.A., D’Antonio, C. M., Swetnam, T.W. 2011. The human dimension of fire regimes on Earth. Journal of Biogeography 38 (12), 2223-2236. http://doi.org/10.1111/j.1365- 2699.2011.02595.x.

Castel, C. 1873. Noticias físico-naturales de la sección NO de la Provincia de Guadalajara. Revista Forestal T. VII, 216-225 and 254-257.

Castellnou, M., Larrañaga, A., Miralles, M., Vilalta, O., Molina, D. 2010. Wildfire scenarios: Learning from experience. In: J.S. Silva, F. Rego, P. Fernandes, E. Rigolot (Eds.). Towards Integrated Fire Management - Outcomes of the European Project Fire Paradox. European Forest Institute, Finland, 228 pp.

Castellnou, M., Miralles, M., Molina, D. 2009. Patrones de propagación de incendios forestales y su uso para la planificación. In: R. Vélez Muñoz (Ed.). Incendios Forestales: Fundamentos y Aplicaciones. McGraw-Hill, pp. 274-282.

Cissel, J.H., Swanson, F.J., Weisberg, P.J. 1999. Landscape management using historical fire regimes: Blue River, Oregon. Ecological Applications 9 (4), 1217-1231. 
Comíns, J.S., Moreno, D.R. 2011. Atlas de los paisajes de la provincia de Guadalajara. Servicio de publicaciones Universidad de Alcalá, Alcalá de Henares.

Costa, P., Castellnou, M., Larrañaga, A., Miralles, M., Kraus, D. 2011. Prevention of Large Wildfires using the fire types concept. UT GRAF-Generalitat de Catalunya, Barcelona, $87 \mathrm{pp}$.

Coughlan, M. R., Petty, A. M. 2012. Linking humans and fire: A proposal for a transdisciplinary fire ecology. International Journal of Wildland Fire 21(5), 477-487. https://doi.org/10.1071/ WF11048.

Coughlan, M.R., Petty, A.M. 2013. Fire as a dimension of historical ecology: A response to Bowman et al. (2011). Journal of Biogeography 40 (5), 1010-1012..https://doi.org/10.1111/ j.1365-2699.2012.02767.x

Delgado Viñas, C. 2015. Agrarian dynamics and landscape in rural mountain areas of Spain. Journal of Settlements and Spatial Planning 4, 145-154.

Duane, A., Piqué, M., Castellnou, M., Duane, A. 2015. Predictive modelling of fire occurrences from different fire spread patterns in Mediterranean landscapes. International Journal of Wildland Fire 24 (3), 407-418..https://doi.org/10.1071/WF14040

European Commission. 2017. Forest Fires in Europe, Middle East and North Africa 2016 Scientific and Technical Research Series. JRC Technical Reports. Publications Office of the European Union, Luxembourg. https://doi.org/10.2760/17690.

Fernández-Muñoz, S. 2002. Consecuencias socioeconómicas y territoriales de las repoblaciones forestales en el Alto Sorbe (Guadalajara). Eria 58, 183-203.

Fernández-Muñoz, S., Mata Olmo, R. 2000. Pasado y presente de las repoblaciones forestales en montes de sociedades de vecinos. Estudios Geográficos 240, 461-486.

Gallardo, M., Gómez, I., Vilar, L., Martínez-Vega, J., Martín, M. P. 2016. Impacts of future land use/land cover on wildfire occurrence in the Madrid region (Spain). Regional Environmental Change 16 (4), 1047-1061. https://doi.org/10.1007/s10113-015-0819-9.

Gil García, M.J. 1992. Dinámica de la paleovegetación en el sector oriental del Sistema Central Español durante el Holoceno, en base al análisis polínico. Implicaciones climáticas. $\mathrm{PhD}$ Thesis, Universidad de Alcalá.

Gómez-Mendoza, J. 1967. La venta de baldios y comunales en el siglo XVI. Estudio de su proceso en Guadalajara. Estudios Geográficos 109, 499-559.

Hernández Vera, T., Ruiz Zapata, B. 1984. Datos preliminares de los análisis polínicos de las tollas ubicadas en Galve de Sorbe (Guadalajara). Anales de la Asociación de Palinólogos de Lengua Española 1,71-76.

Hernando, J., Madrazo, G. 2016. Firewood and charcoal consumption in Madrid during eighteenth century and its effects on forest landscapes. In: E. Vaz, C. Joanaz de Melo, L.M. Costa Pinto (Eds.). Environmental history in the making. Environmental History, 6. Springer International Publishing, pp. 321-340. https://doi.org/10.1007/978-3-319-41085-2_18.

Jerez, D.P., Fernández-Such, F., Martín, B O.,Llanes, Ó.M. 2004. Las zonas rurales en España: Un diagnostico desde la perspectiva de las desigualdades territoriales y los cambios sociales y económicos. Caritas Española, Madrid.

Keeley, J.E. 2011. Fire in Mediterranean ecosystems. Israel Journal of Ecology \& Evolution 58, 123-135. https://doi.org/10.1017/CBO9781139033091.

Keeley, J.E., Bond, W.J., Bradstockd, R.A., Pausas, J.G., Rundel, P.W. 2012. Fire in the Mediterranean Ecosystems - Ecology, Evolution and Management. Cambridge University Press, Cambridge.

Krebs, P., Pezzatti, G.B., Mazzoleni, S., Talbot, L.M., Conedera, M. 2010. Fire regime: history and definition of a key concept in disturbance ecology. Theory in Biosciences 129 (1), 53-69. https://doi.org/10.1007/s12064-010-0082-z. 
LaCroix, J.J., Ryu, S.R., Zheng, D., Chen, J. 2006. Simulating fire spread with landscape management scenarios. Forest Science 52 (5), 522-529.

Lloret, F., Marí, G. 2001. A comparison of the medieval and the current fire regimes in managed pine forests of Catalonia (NE Spain). Forest Ecology and Management 141 (3), 155-163. https://doi.org/10.1016/S0378-1127(00)00323-6.

Lopéz-Gómez, A. 1974. Colectivismo y sistemas agrarios de la Serranía de Atienza (Guadalajara). Estudios Geográficos 35, 137-519.

Martínez-Vega, J., Díaz, A., Nava, J.M., Gallardo, M., Echavarría, P. 2017. Assessing land usecover changes and modelling change scenarios in two mountain Spanish national parks. Environments 4 (4), 79. https://doi.org/10.3390/environments4040079.

Mata Olmo, R., Sanz Herráiz, C.S. (Eds.) 2004. Atlas de los Paisajes de España. Centro de Publicaciones Ministerio de Medio Ambiente, Madrid.

Mazzoleni, S., di Pasquale, G., Mulligan, M., di Martino, P., Rego, F. 2004. Recent dynamics of the Mediterranean Vegetation and Landscape. Wiley.

Mecha-López, P. 2004. Modelizacion territorial aplicada a la gestiónfForestal en la vertiente sur de la Sierra de Ayllón. PhD Thesis. Escuela Técnica Superior de Ingenieros de Montes., Universidad Politécnica de Madrid.

Millington, J.D.A., Perry, G.L.W., Romero-Calcerrada, R. 2007. Regression techniques for examining land use/cover change: A case study of a Mediterranean landscape. Ecosystems 10 (4), 562-578. https://doi.org/10.1007/s10021-007-90204.

Montejano, N.G. 1988. Apuntes en torno a la organización comunitaria de la Comarca de Ayllón (Segovia). Anales del Museo del Pueblo Español. Dirección General de Bellas Artes y Bienes Culturales, Segovia, pp. 171-178.

Montiel-Molina, C. 2003. Tradición, renovación e innovación en los usos y aprovechamientos en las áreas rurales de montañas. Cuadernos Geográficos 33, 7-26.

Montiel-Molina, C. 2013. Presencia histórica del fuego en el territorio. Ministerio de Agricultura y Pesca Alimentación y Medio Ambiente (MAPAMA), Madrid.

Montiel-Molina, C., Galiana-Martín, L. 2016. Fire scenarios in Spain: a territorial approach to proactive fire management in the context of global change. Forests 7 (273), 1-17. https://doi. org/10.3390/f7110273.

Montiel-Molina, C., Karlsson-Martín, O., Galiana-Martín, L. 2018. Regional fire scenarios in Spain: Linking landscape dynamics and fire regime for wildfire risk management (in revision). Journal of Environmental Management 233, 427-439. https://doi.org/10.3390/f7110273.

Montiel, C., Herrero, G. 2010. Overview of policies and practices related to fire ignitions. In: J. Sande Silva, F. Rego, P. Fernandes, E. Rigolot (Eds.), Towards Integrated Fire ManagementOutcomes of the European Project Fire Paradox European Forest Institute, Joensuu, pp. 3546.

Murphy, B.P., Bradstock, R.A., Boer, M.M., Carter, J., Cary, G.J., Cochrane, M.A., Bowman, D.M.J.S. 2013. Fire regimes of Australia: A pyrogeographic model system. Journal of Biogeography 40 (6), 1048-1058. https://doi.org/10.111/jbi.12065.

O’Connor, C.D., Garfin, G.M., Falk, D.A., Swetnam, T.W. 2011. Human Pyrogeography: A New Synergy of Fire, Climate and People is Reshaping Ecosystems across the Globe. Geography Compass 5 (6), 329-350. https://doi.org/10.1111/j.1749-8198.2011.00428.x.

Ollero, H.S., Juaristi, C.M., Maldonado Ruiz, J., García Antón, M., Múgica, F. 2001. Evolución de la vegetación en el sector septentrional del macizo de Ayllón (Sistema Central). Análisis polínico de la turbera de Pelagallinas. Anales Del Jardín Botánico de Madrid 59 (1), 113-124.

Hoggart, K., Paniagua, A. 2001. The restructuring of rural Spain? Journal of Rural Studies 17(1), 63-80. https://doi.org/10.1016/S0743-0167(00)00037-1. 
Pascual, F. G. 2006. Políticas públicas y sustentabilidad en las zonas desfavorecidas y de montaña en España. Boletín de la Asociación de Geógrafos Españoles 41, 151-182.

Pausas, J. G., Paula, S. (2012). Fuel shapes the fire-climate relationship: evidence from Mediterranean ecosystems. Global Ecology and Biogeography 21 (11), 1074-1082. https:// doi.org/10.1111/j.1466-8238.2012.00769.x.

Pausas, J.G., Llovet, J., Anselm, R., Vallejo, R. 2008. Are wildfires a disaster in the Mediterranean basin? - A review. International Journal of Wildland Fire 17 (6), 713-723. http://doi. org/10.1071/WF07151

Pérez, B., Moreno, J.M. 1998. Fire-type and forestry management effects on the early postfire vegetation dynamics of a Pinus pinaster woodland. Plant Ecology 134 (1), 27-41. https://doi. org/10.1023/A:1009733818670.

Pyne, S.J. 1997. World Fire - The Culture of Fire on Earth. University of Washington Press, Washington.

Roos, C.I., Bowman, D.M.J.S., Balch, J.K., Artaxo, P., Bond, W.J., Cochrane, M.A., Swetnam, T.W. 2014. Pyrogeography, historical ecology, and the human dimensions of fire regimes. Journal of Biogeography 41, 833-836. https://doi.org/10.1111/jbi.12285.

Ruiz Zapata, B., Andrade Olalla, A., Gil García, M.J., Dorado Valiño, M., Atienza Ballano, M. 1996. Evolución de la vegetación en los últimos 6000 años en los sectores central y oriental del Sistema Central Español. Revista Española de Paleontología $\mathrm{N}^{\circ}$ Extraordinario, 288298.

San-Miguel-Ayanz, J., Chuvieco, E., Handmer, J., Moffat, A., Montiel, C., Sandahi, L., Viegas, D. 2017. Climatological risk: wildfires. In: K. Poljansek, M. Martin Ferrer, T. De Groeve, I. Clark (Eds.), Science for disaster risk management 2017: knowing better and losing less. Publications Office of the European Union, Luxembourg, pp. 294-305. https://doi. org $/ 10.2788 / 688605$.

Scott, A. 2018. BurningpPlanet - The story of fire throughtTime. Oxford University Press.

Silva, J.S., Rego, F.C., Fernandes, P.M., Rigolot, E. 2010. Towards Integrated Fire Management Outcomes of the European Project Fire Paradox. European Forest Institute.

Smith, A.M.S., Kolden, C.A., Paveglio, T.B., Cochrane, M.A., Bowman, D.M.J.S., Moritz, M.A., Abatzoglou, J.T. 2016. The Science of firescapes: Achieving fire-resilient communities. BioScience 66 (2), 130-146. https://doi.org/10.1093/biosci/biv182.

Stellmes, M., Röder, A., Udelhoven, T., Hill, J. 2013. Mapping syndromes of land change in Spain with remote sensing time series, demographic and climatic data. Land Use Policy, 30 (1), 685-702. https://doi.org/10.1016/j.landusepol.2012.05.007.

Tedim, F., Xanthopoulos, G., Leone, V. 2014. Forest Fires in Europe: Facts and Challenges. In: D. Paton (Ed.), Wildfire hazards, risks, and disasters. Elsevier, Amsterdam, pp. 77-99. https:// doi.org/10.1016/B978-0-12-410434-1.00005-1.

Tolón Becerra, A., Lastra Bravo, X.B. 2007. Evolución del desarrollo rural en Europa y en España: las áreas rurales de metodología LEADER. $M+A$, Revista Electrónica de Medioambiente 4, 35-62.

Turco, M., Bedia, J., Di Liberto, F., Fiorucci, P., Von Hardenberg, J., Koutsias, N., Provenzale, A. 2016. Decreasing fires in Mediterranean Europe. PLOS ONE 11 (3). https://doi.org/10.1371/ journal.pone.0150663.

Vadell, E., de-Miguel, S., Pemán, J. 2016. Large-scale reforestation and afforestation policy in Spain: A historical review of its underlying ecological, socioeconomic and political dynamics. Land Use Policy 55, 37-48. https://doi.org/10.1016/j.landusepol.2016.03.017.

Vélez Muñoz, R. 2009. La defensa contra incendios forestales - Fundamentos y experiencias. McGraw-Hill. 
Viedma, O., Moity, N., Moreno, J.M. 2015. Changes in landscape fire-hazard during the second half of the 20th century: Agriculture abandonment and the changing role of driving factors. Agriculture, Ecosystems and Environment 207, 126-140. https://doi.org/10.1016/j. agee.2015.04.011.

Viedma, O., Moreno, J. M., Rieiro, I. 2006. Interactions between land use/land cover change, forest fires and landscape structure in Sierra de Gredos (Central Spain). Environmental Conservation 33, 212-222. https://doi.org/10.1017/s0376892906003122.

Wilbanks, T.J., Kates, R.W. 1999. Global change in local places: How scale matters. Climatic Change 43 (3), 601-628. https://doi.org/10.1023/A:1005418924748. 